\title{
ELECTRODIAGNOSTIC INVESTIGATION OF THE MOTOR NEURON AND SPINAL REFLEX ARCH (H-REFLEX) IN SPINAL CORD INJURY
}

\author{
By Y. Shemesh, M.D., R. Rozin, M.D. and A. Ohry, M.D. \\ Sir Ludwig Guttmann Spinal Cord Injury Centre, Ch. Sheba Medical Centre, Tel-Hashomer, \\ Tel-Aviv University, School of Medicine, Israel
}

\section{Introduction}

A BATTERY of electromyographic tests was used in a group of 20 paraplegic and quadriplegic patients. Activities of fibrillar type were recorded especially in the spinal shock phase. A study of nerve conduction velocities in tibial nerves revealed a significant slowing in both nerves compared with the standards for completely normal subjects. H-reflex studies revealed an increase in the mean $\mathrm{H} / \mathrm{M}$ ratio with no clear correlation between the $\mathrm{H} / \mathrm{M}$ ratio and the degree of clinical spasticity. When investigations were repeated during a period of physical activity they showed a trend to reduction of the $\mathrm{H} / \mathrm{M}$ ratio.

\section{Review of Literature}

Contradictory reports in the literature dispute the presence of electromyographic abnormalities in hemiplegic patients. Bahala (I969), Goldkamp (I97I) and Krueger and Waylonis (I973), reported fibrillation potentials and positive waves in muscles of 62 to $8 \mathrm{I}$ per cent of hemiplegic patients. These signs generally appear as early as I week after onset and over I year later. But Alpert et al. (I97I, 1973) failed to find significant EMG disturbances in two groups of hemiplegic patients. In patients with spinal cord injury, Nyboer and Johnson (I97I), Rosen et al. (1969), Taylor (1974) Onkelinx (1975) and Spielholtz et al. (1972), have found fibrillation potentials and positive waves in muscles below levels of injury, especially in the spinal shock phase. Most of the investigators who found this disturbance made the assumption that these abnormalities result from lower motor neuron degeneration. In animals with spinal cord transection, Warrington (I889) has observed histological changes in the anterior horn cells and internuncial pool.

Study of nerve conduction velocity (NCV) in patients with upper motor neuron lesions generally has been considered to beinsignificant. Sutton et al. (1967) and Panin et al. (1965), had not found significant difference in peroneal NCV between affected and unaffected sides. But Widener et al. (1967), Cowley et al. (1967), and Kyoichi et al. (1975), reported a significant decrease in the NCV of both ulnar and peroneal nerves in the affected extremities of hemiplegic patients. Most of these investigators believe that the reduction in NCV may be caused by functional and morphological changes in the lower motor neuron (and its fibre) bereft of upper motor neuron influences.

Since its description in I9I 8 by Hoffman, the physiology and clinical significance of the H-reflex have been discussed in great detail by many authors. The monosynaptic nature of the reflex has been confirmed in cats by Lloyd (I943), and 
in man by Magladery et al. (1950, I95I, I952). Angel and Hoffman (1963), Miglietta (1968), Matthews (I970), Carcia-Mullin (I972) and Spira (I974), believe the H-reflex to be a true reflection of the excitability of alpha motor neurons and have used it to objectively measure spasticity. It has been claimed that greater reliability is obtained by observing and comparing the largest amplitudes of the H-reflex $(\mathrm{H})$ and of the direct motor wave $(M)$ in this way the so-called $\mathrm{H}$-max./M-max. ratio can be established. It was found by standardised techniques that this ratio varies in normal individuals between I and 3 per cent. In spastic patients, the ratio is often many times larger than this.

\section{Material and Methods}

We examined 20 patients aged between I 5 and 49 years, I 7 of whom were males. Patients liable to be suspected of peripheral neuropathy have been systematically discarded (lesions of $\mathrm{LI}_{\mathrm{I}}$, of the conus medullaris and diabetes Mellitus). The aetiology was traumatic for all patients, which included eight quadriplegics, and $\mathrm{I}_{2}$ paraplegics. The level of the lesion was between $\mathrm{C}_{5}$ and TII, I9 were complete and one incomplete. All those patients were spastic and hyperreflexive. Times from injury to examination were ranged from I month to 27 years.

Studies were performed with the subject lying prone. Electromyography was performed with coaxial needle electrodes using a Medelc model. The peroneal and the posterior tibial nerves were selected for the nerve conduction velocity studies. The peroneal nerve was stimulated at the knee and the ankle, with the responses recorded by pick-up surface electrodes from the extensor digitorum brevis muscle the reference electrode being placed near the lateral edge of the foot. For posterior tibial stimulations, the recording electrode was placed on the abductor hallucis muscle. The nerve was stimulated at the knee and the ankle. Skin temperatures of the lower extremities were measured with a thermometer.

In each case, the posterior tibial nerve was stimulated in the popliteal fossa, percutaneously by square wave electrical stimuli, 0.5 minutes' duration. Muscle action potentials were recorded by surface electrodes taped to the skin surface. One electrode was placed over the bellies of the calf muscles and the other over the Achilles tendon. The stimulus current was increased in steps until a complete stimulus-response curve was obtained; a further increase of at least 25 per cent ensured that a supramaximal $M$ response has been obtained. By dividing the $\mathrm{H}$-max./M-max. we obtained the ' $\mathrm{H} / \mathrm{M}$ ' ratio. Five of the total 20 patients were re-examined, and changes in fibrillar activity and $\mathrm{H} / \mathrm{M}$ ratio were recorded.

\section{Results}

Six patients have shown at one or another stage of their affliction, fibrillation potentials in the lower extremities muscles. However, these signs seem to decrease as time goes on. Two patients who exhibited fibrillation potentials at the 4 th month, no longer presented them at the 6th month. The third, showing similar findings on the 7 th month failed to present them at the 9 th month. In the fourth patient, fibrillation potentials appeared after the ist month. The other two patients presented fibrillation potentials on the 6th and 27th months, respectively (Table I).

Forty determinations of motor conduction velocity (20 corresponding to posterior tibial nerves) have revealed normal values I4 times for posterior tibial 
TABLE I

Fibrillation potentials in spinal cord injury

\begin{tabular}{lcccc}
\hline & $\begin{array}{c}\text { Time of } \\
\text { examination } \\
\text { after injury } \\
\text { (months) }\end{array}$ & Ist examination & 2nd examination & 3rd examination \\
Patient & $4-6$ & + & - & - \\
H. Y. & $4-6$ & + & + & - \\
M. M. & $7-9$ & + & + & + \\
R. Y. & I-3 & - & + & \\
H. M. & 6 & + & & \\
H. C. & 27 & + & & \\
S. S. & & & & \\
\hline
\end{tabular}

nerves (Tables II and III). The common peroneal nerves show much less favourable results: there are only nine normal values for five non-measurable ones and six lowered.

Four patients have measurable NCV at the posterior tibial nerves and nonmeasurable NCV at the anterior ones. One patient has no measurable velocity at all, due to oedema at the ankles. The oldest patient, 49 years old, was examined 27 years after injury, and showed lowered NCV in both nerves.

When the determination of motor NCV is possible ( 33 times out of 40 ), the values obtained are normal in 23 instances. The case of non-measurable motor NCV corresponds generally to determination of the anterior tibial nerves (five times out of seven).

\section{TABLE II}

Normal motor NCV in the peroneal and post-tibial nerves

\begin{tabular}{lcc}
\hline \multicolumn{1}{c}{ Reference } & Peroneal nerves & Posterior tibial nerves \\
\hline Thomas, Sears, Gilliat & $49 \cdot 7 \pm 7 \cdot \mathrm{I}$ & $43 \cdot 2 \pm 4 \cdot 9$ \\
Johnson, Olsen & $50 \cdot \mathrm{I} \pm 7 \cdot 2$ & $50 \cdot 2 \pm 9 \cdot 3$ \\
Schubert & $46 \cdot 7 \pm 7 \cdot 4$ & $45 \cdot 7 \pm 3 \cdot 6$ \\
Takebe, Basamajian & $46 \cdot 1 \pm 4 \cdot 3$ & $45 \cdot 8 \pm 3 \cdot 0$ \\
'Mean' of groups & $48 \cdot 9 \pm 7 \cdot \mathrm{I}$ & $45 \cdot 6 \pm 4 \cdot 7$ \\
\hline
\end{tabular}

\section{TABLE III}

Motor conduction velocity of tibial nerves

\begin{tabular}{|c|c|c|c|c|}
\hline & No. measurements & Normal & Not measurable & Decreased \\
\hline Post tibial n. & 20 & I 4 & 2 & 4 \\
\hline Peroneal n. & 20 & 9 & 5 & 6 \\
\hline Total & 40 & 23 & 7 & IO \\
\hline
\end{tabular}




\section{TABLE IV}

$\mathrm{H} / \mathrm{M}$ ratios in follow-up study

\begin{tabular}{|c|c|c|c|c|}
\hline Patient & $\begin{array}{l}\text { Time of } \\
\text { examination } \\
\text { after injury } \\
\text { (months) }\end{array}$ & $\begin{array}{l}\mathrm{H} / \mathrm{M} \text { ratio } \\
\text { Ist } \\
\text { examination }\end{array}$ & $\begin{array}{l}\mathrm{H} / \mathrm{M} \text { ratio } \\
\text { 2nd } \\
\text { examination }\end{array}$ & $\begin{array}{c}\mathrm{H} / \mathrm{M} \text { ratio } \\
\text { 3rd } \\
\text { examination }\end{array}$ \\
\hline H. M. & I-3 & $0 \cdot 10$ & 0.08 & 0.07 \\
\hline F. P. & $I-3$ & 0.43 & 0.37 & 0.35 \\
\hline H. Y. & $4-6$ & 0.66 & 0.33 & 0.23 \\
\hline M. M. & $4-6$ & 0.07 & 0.00 & 0.00 \\
\hline R. Y. & 7-9 & 0.50 & 0.43 & $0.4 \mathrm{I}$ \\
\hline
\end{tabular}

The decrease of NCV did not seem to relate to any of the following factors: (I) duration of the lesion; (2) degree of paralysis and (3) degree of spasticity.

All patients showed the H-reflex. One case failed to show an $\mathrm{H}$-wave in the follow-up study. Changes in stimulus intensity produced characteristic effects upon the size of the $M$ and $H$ waves. $H / M$ ratios were plotted for all patients, and the mean value was found to be 0.34 , with a range of 0.07 to 0.80 . The high $\mathrm{H} / \mathrm{M}$ ratios obtained in some patients did not always tally with similarly increased spasticity. The majority of cases with lower clinical spasticity had $\mathrm{H} / \mathrm{M}$ ratios in lower values.

Five of the total 20 patients were re-examined and the $H / M$ ratio re-measured. All of them had received daily sessions of physical activities during the intervening period. The clinical re-examinations showed no appreciable differences in gross spasticity between the examinations. A decrease in the $\mathrm{H} / \mathrm{M}$ ratio was found in all five patients (Table IV). This decrease was greater in those whose initial $\mathrm{H} / \mathrm{M}$ ratios had been very high. The decrease ranged from a third to a half. In those cases in which the initial $\mathrm{H} / \mathrm{M}$ ratio had been lower, the re-examination showed a smaller decrease in the ratio, ranging between 5 and io per cent. One case failed to show the H-wave in the follow-up study.

Passive muscle stretch brought an increase in the amplitude of the H-wave. Double peaked or irregular $\mathrm{H}$-waves were found only in five patients. The latency of the H-wave was within normal limits.

\section{Discussion}

Fibrillation potentials and positive sharp waves are not synonomous with denervation. They represent a hyper-irritable state of the muscle cell membrane. The fibrillation potential is the resultant electrical activity of a single muscle cell membrane discharging spontaneously.

A number of investigators have found fibrillation potentials in spinal cord injury patients, especially in the spinal shock phase. It must nevertheless be emphasised that one of our patients has kept fibrillation potentials after 27 months. Similar findings were observed by Nyboer and Johnson (I97I), Spielholtz et al. (I972) and Onkelinx and Chantraine (I975).

In order to explain the curious, spontaneous abnormal electromyographic findings, various possibilities may be considered. Spielholtz et al. (1972) offer the 
hypothesis of an antifibrillar factor, synthesised in the anterior horn cells. In an upper motor lesion the anterior horn cells are deprived of this factor.

Warrington (I889) and other investigators mentioned by Spielholtz et al. (I972), have observed histological changes in the anterior horn cells after spinal cord transection. Most investigators, therefore, assume a trophic effect, accomplished by the upper motor neuron on the anterior horn cells. Its abolition would, in certain conditions, determine the occurrence of fibrillation and positive waves.

Study of the nerve conduction velocity (NCV) requires strictness, both in methodology and in the choice of the patients studied, to exclude any peripheral nerve lesions, clinically silent. Certain difficulty arose in determining some of them, since they are not always measurable according to Onkelinx (1975). The case of non-measurable motor NCV corresponds generally to determination of the common peroneal nerves. The reason is probably due to the fact that the extensor communis brevis is very rapidly atrophied after local injury or common aggressions by shoes or certain apparatus. That is why the extensor communis brevis is known as a poor revelator of evoked potentials.

Our finding of a significant slowing in the NCV of both tibial and peroneal (ten times out of 33 successful measures) indicates that lower motor neurons are indeed affected by upper motor neuron lesions. Variation in the evoked potentials also suggests the existence of a lower motor neuron abnormality. Similar findings were found in hemiplegic patients. The decrease of NCV has several probable and cumulative causes. Not the least of these may be a functional or morphological change in the motor neuron (and its fibre) bereft of upper motor neuron influences. A temperature reduction and decreased diameter of the nerve fibre as a result of muscle atrophy could also lead to a decreased NCV.

Another object of the present study was to evaluate the H-reflex as an index of the spastic state. Our own findings show a marked parallelism between the clinical impressions of hypertonus of the lower limbs and the $H / M$ ratios. The $\mathrm{H} / \mathrm{M}$ was smaller for the less spastic legs. On the other hand, a high $\mathrm{H} / \mathrm{M}$ ratio did not necessarily correspond to a high degree of clinical spasticity. The regulation and mediation by muscle spindles and increased fusiform activity may explain this finding.

The results in our group of patients who were re-examined after a period of physical activity can be taken as suggesting a decrease in the proportion of the population of alpha motor-neuron pools, which are susceptible to reflex excitation, and by so doing, reduces the spasticity of the lower limbs. No clinical confirmation of the reduction of spasticity was found. Our studies do not allow us to state for how long that reduction persists.

\section{SUMMARY}

Twenty patients with spinal cord injury underwent serial electromyographic examinations. Fibrillation potentials and positive waves were noted in six patients in the spinal shock phase. In another subject, these potentials were found 27 months after injury. Our finding of significant slowing in the NCV of both nerves, indicates that lower motor neurons are indeed affected by upper motor neuron lesions.

The H-reflex studies showed an increase in the mean $\mathrm{H} / \mathrm{M}$ ratio. This may indicate an increase of reflex motor neuron excitability. No clear correlation was found between this increase and the degree of clinical spasticity. With repeat investigations, after a period of physical activity, a trend to reduction of the $\mathrm{H} / \mathrm{M}$ ratio was noted with no clinical confirmation of reduction in spasticity. 
These findings emphasise the need for not assigning diagnostic terms to EMC abnormalities, but rather identifying them as neurophysiological changes which must be interpreted in the light of the clinical picture.

\section{RÉSUMÉ}

20 malades souffrant de lésions de l'épine dorsale ont subi une série d'examens électromyographiques. Des potentiels de fibrillation ainsi que des courbes positive sont été notés chez 6 patients dans la phase de choc spinal. Chez un autre malade, ces phénomènes sont apparus 27 mois après la blessure. Nous avons constaté un ralentissement significatif de la vitesse de la conduction nerveuse qui indique clairement que les neurones moteurs inférieurs sont affectés par les lésions des neurones moteurs supérieurs.

L'étude du réflexe d'Hoffman a révélé une augmentation de la valeur $\mathrm{H} / \mathrm{M}$ moyenne. Ceci pourrait indiquer une augmentation de l'excitabilité due neurone moteur réflexe. Aucune corrélation nette n'a été trouvée entre cette augmentation et le degré de spasticité clinique. Des examens répétés après une période d'activité physique ont montréune tendance à la réduction de la valeur $\mathrm{H} / \mathrm{M}$ sans confirmation clinique de la diminution de la spasticité.

Ces résultats prouvent la nécessité de ne pas doter de termes diagnostiques les anormalités électromyographiques, mais plutôt d'identifier celles-ci comme changements neurophysiologiques qui doivent être interprétés à la lumière des données cliniques.

\section{ZUSAMMENFASSUNG}

Zwanzig Patienten mit Rückenmarkverletzungen wurden elektromyographischen Untersuchungen unterzogen. Fibrillationspotentiale mit Positivwellen wurden bei sechs, in spinaler Schockphase sich befindenden Kranken verzeichnet. Diese Potentiale konnten auch bei einem Patienten 27 Monate, die der Verletzung folgten, festgestellt werden. Unsere Befunde über bedeutsame Verlangsamungen in Nervleitungsgeschwindigkeit (NCV) der beiden Nervengattungen weisen darauf hin, dass bei Verletzungen des oberen Motorneurons auch die unteren Motorneurons mit betroffen werden.

Studien des H-Reflexes ergeben einen durchschnittlichen Anstieg des H/M Quotienten. Dieser Befund kann als Ausdruck einer gesteigerten Reizbarkeit des Obermotorneurons gedeutet werden. Anderseits liess sich keinerlei Wechselbeziehung zwischen dieser Reizsteigerung und dem klinischen Verkrampfungsgrade nachweisen. Bei wiederholten Nachuntersuchungen, die Zeitabschnitten von körperlichen Betätigungen folgten, bestand die Tendenz zur Verminderung des $\mathrm{H} / \mathrm{M}$ Quotienten bei gleichbleibenden Spastizitäten.

Nach diesen Befunden ist es notwendig, die EMC-Erscheinungen als neurophysiologische Veränderungen anzuerkennen und sie nicht mit Sonderbezeichnungen belegen.

\section{REFERENCES}

Alpert, S., Idarraga, S. \& Orbegozo, J. et al. (I97I). Absence of electromyographic evidence of lower motor neurone involvement in hemiplegic patients. Arch. Phys. Med. Rehabil. 52, I79.

Alpert, S., Jarrett, S., Lerner, I. \& Rosenthal, A. (I973). Electromyographic findings in early hemiplegia. Arch. Phys. Med. Rehabil. 54, Io, 464.

Angel, R. W. \& HofFMAnN, W. W. (1963). The H-reflex in normal, spastic, and rigid subjects. Arch. of Neurolog. 8, 59I.

BAHALA, R. P. (I969). Electromyographic evidence of lower motor neuron involvement in hemiplegia. Arch. Phys. Med. Rehabil. 50, 632.

Cowley, L. H., Cress, R. H. \& Fleming, W. C. (I967). Motor nerve conduction velocity studies on lower extremities of hemiplegics. South Med. F. 60, I324.

Garcia-Mullin, R. \& Mayer, R. F. (I972). H-reflex in acute and chronic hemiplegia. Brain, 95, 559 .

GolDKAMP, O. (I967). Electromyography and nerve conduction studies in I 6 patients with hemiplegia. Arch. Phys. Med. Rehabil. 48, 59.

Hoffman, P. (I9I8). Uber die Beziehungen der Sehnenreflexe zur wilkurlichen Bewegung und zum Tonus. Z. Biol. 68, 35I. 
KRUEGER, K. \& WAYLONIS, G. (I973). Hemiplegia: lower motor neuron electromyographic findings. Arch. Phys. Med. Rehabil. 54, 360.

KYOICHI, T., MYsORE, D. N., CARL, K. \& JOHN, V. B. (1975). Slowing of nerve conduction velocity in hemiplegia: possible factors. Arch. Phys. Med. Rehabil. 56, 285.

Lloyd, D. P. C. (1943). Neuron patterns controlling transmission of ipsilateral hind limb reflexes in cat. $\mathcal{F}$. Neurophysiol. 6, 293.

MAgladery, J. W. \& MCDOugal, D. B. JR. (1950). Electrophysiological studies of nerve and reflex activity in normal man. I. Identification of certain reflexes in the electromyogram and the conduction velocity of peripheral nerve fibres. Bull. Fohns Hopkins Hosp. 86, 265.

Magladery, J. W., Porter, W. E., Park, A. M. \& Teasdall, R. D. (I95I). Electrophysiological studies of nerve and reflex activity in normal man. IV. The two-neurone reflex and identification of certain action potentials from spinal roots and cord. Bull. fohns Hopkins Hosp. 88, 499.

Magladery, J. W., Teasdall, R. D., Park, A. M. \& Languth, H. W. (I952). Electrophysiological studies of reflex activity in patients with lesions of the nervous system. I. A comparison of spinal motor neuron excitability following afferent nerve volleys in normal patients and patients with upper motor neuron lesions. Bull. Fohns Hopkins Hosp. 91, 219.

MattheWs, W. B. (I970). The clinical implications of the H-reflex and of other electrically induced reflexes. In Modern Trendsin Neurology-5, ed.C. D. Williams. Butterworths, London, p. 24I.

Miglietta, O. (I968). Afferent influence on spinal motor neurons excitability of normal subjects and spastic patients. Archives of Physical Medicine, 49, 708.

Namba, R., Schuman, M. H. \& Grob, D. (I97I). Conduction velocity in ulnar nerve in hemiplegic patients. F. Neurol. Sci. 12, I77.

Nyboer, V. J. \& Johnson, H. E. (I97I). Electromyographic findings in lower extremities of patients with traumatic quadriplegia. Arch. Phys. Med. Rehabil. 52, 256.

Onkelinx, A. \& Chantraine, A. (1975). Electromyographic study of paraplegic patients. Electromyogr. Clin. Neurophysiol. 15, 7I.

Panin, N., PAul, B. J. \& PolicofF, L. D. (I965). Nerve conduction velocities in hemiplegia: preliminary report. Arch. Phys. Med. Rehabil. 46, 467.

Rosen, J. W., LeRner, I. M. \& Rosenthal (1969). Electromyography in spinal cord injury. Arch. Phys. Med. Rehabil. 50, 27 I.

Spielholtz, N., Sell, G. H., Goodgold, J., Rusk, H. \& Greehs, S. (I972). Electrophysiological studies in patients with spinal cord lesions. Arch. Phys. Med. Rehabil. 53, 558.

SPIRA, R. (1974). Contribution of the H-reflex to the study of spasticity in adolescents. Dev. Med. E Child Neurol. 16, 2, I50.

Sutton, L. R., Cohen, B. S. \& Krusen, U. L. (1967). Nerve conduction studies in hemiplegia. Arch. Phys. Med. Rehabil. 48, 64.

TAYlor, R. G., KeWalramani, L. S. \& FowleR, W. M. (1974). Electromyographic findings in lower extremities of patients with high spinal cord injury. Arch. Phys. Med. Rehabil. 55, I, I6.

WARRINGTON, W. (I889). Further observations on structural alterations observed in nerve cells. F. Phys. 24, 464.

WidenER, T., CREss, R. H. et al. (1967). Studies on velocity of nerve conduction in hemiplegics. South Med. F. 60, I I94. 